\title{
Direct Shear Strength Properties of Limestone-Blended Embankment Materials
}

\author{
Jonathan R. Dungca ${ }^{1 *}$ \\ ${ }^{1}$ Civil Engineering Department, De La Salle University Manila, 2401 Taft Avenue, 1004 Manila, Philippines \\ *Corresponding author: jonathan.dungca@dlsu.edu.ph
}

\begin{abstract}
The vast distribution of limestone in the Philippines makes limestone quarrying prevalent resulting to the accumulation of waste limestone. This opened the idea of utilizing the wastes as embankment materials which would result to a more economical construction. In order to test the ability of limestone to be an embankment material, its strength and consolidation parameters are evaluated in different mixed proportions, at $0 \%, 20 \%, 40 \%, 60 \%$ and $100 \%$, with the conventional embankment material using the direct shear test. Index properties (i.e. specific gravity, Atterberg limits, and maximum and minimum index densities) were obtained for all the blends in order to produce empirical relationships with the different percentage of limestone. It was found out that the cohesion increased with the addition of limestone, although there was a decrease in the internal angle of friction.
\end{abstract}

Keywords—Waste Limestone, Embankment, Direct Shear.

\section{INTRODUCTION}

$\mathrm{T}$ oday, it is apparent that it is difficult to find quality embankment materials especially in isolated island and rural areas in the Philippines. Because of this, there is a need to find an alternative source of embankment materials that is accessible and is of good quality. Limestone is a rock which is highly available in the Philippines. In this study, the limestone used is from Guimaras Island. This island is known to have mining area of almost 1800 hectares of limestone. With the vast amount of limestone in the Philippines and its potential to stabilize soil, it was expected that blending this with conventional embankment material will provide strength acceptable as a structural fill.

The main objective of this study is to provide the direct shear strength properties of the blends for foundation design. By doing so, relationships between the geotechnical properties and the properties can be derived.

The usability of a quarry dust limestone powder, a by-product of stone crushers, in self-compacting paste and concrete applications [1]. These by-products pose big problems from aspects such as its disposal, environmental pollution and health hazards.

In the study Performance of Roadway Embankment on Lime Waste by Ramer and Wang, 2000, the mechanical and geotechnical properties of a four lane embankment which was constructed over an abandoned quarry filled with limestone waste in Plymouth Township, Montgomery County Pennsylvania was determined[2]. Based on the test results, it was found out that lime waste is highly compressible, has very low shear strength and cause very large roadway settlements. The result of the journal varies with this study because of the different scenario. In journal, a roadway embankment was placed over the limestone waste while this research would blend together the two materials. While according to Dunlop R. (1980), "The addition of lime to subbases and bases improves the load-spreading ability of the otherwise unbound soil layer by increasing the secant modulus [3]. When high lime contents are used, slab action will develop, and therefore, greater load spreadability of the pavement layer will result, provided intensive internal cracking can be avoided. The lime increases the shear strength of the soils."

\section{TESTING MATERIALS}

The limestone that was used in the research came from a limestone quarry in Guimaras Island in the Cntral Philippines. These limestones were considered waste materials in the limestone quarry, however, have not undergone any treatment. On the other hand, the conventional embankment material was from a mountain quarry in Rizal area.

The waste limestones used were yellowish in color and can easily be crushed. On the other hand, the conventional embankment materials used were grayish in color. For the particle shape, the limestones were subrounded. On the other hand, for the conventional embankment material, the particles range from angular to sub-angular.

The limestones were blended with the conventional embankment material by replacing the fine aggregates passing through the No.4 sieve in proportion of $0 \%$, $20 \%, 40 \%, 60 \%$, and $100 \%$. The weights of every size of aggregate passing through sieve no. 4 were arithmetically computed based on the grain size distribution curve presented in Figure 1. The corresponding percent weight of the limestone and conventional embankment material for every blend is indicated in Table 1 .

\section{TESTING METHODS}

\section{A. Index Properties}

In order to fully understand the behavior of the samples, the geotechnical engineering properties were evaluated for the different blends with the following laboratory tests: 


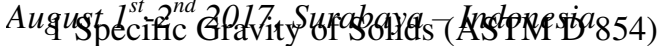

2 Atterberg Limits Test (ASTM D4318 and

(ASTMD427)

3 Maximum Index Density and Unit Weight using Vibratory Table (ASTM D4253)

4 Minimum Index Density and Unit Weight and

Calculation of Relative density (ASTM D4254)

\section{B. Sample Preparation}

The samples that were used for the consolidation and direct shear tests were done by means of moist tamping method. This is a procedure that was suggested by Chao (2008) that can successfully provide a uniform sample for oedometer testing[4]. In this procedure the addition of water is divided into two parts since it is difficult to compact the sample in its fully saturated state. The first part is adding the amount of water that allows the sample to attain optimum moisture content. And the second half is added before the start of the test to make it fully saturated.

The two main requirements in the sample preparation are to prepare them at $90 \%$ to $95 \%$ relative density and to make sure that the sample is fully saturated. To attain a relative density in this range, series of trials was needed in order to attain the right amount of compaction

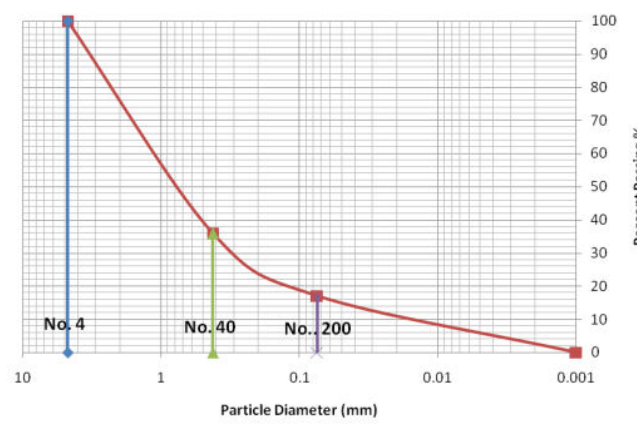

Figure 1. Grain Size Distribution Curve

Table 1. Comparison of two methods in training of OHL-CBPNN

\begin{tabular}{cc}
\hline $\begin{array}{c}\text { Corresponding \% of } \\
\text { Limestone Passing } \\
\text { No.4 Sieve }\end{array}$ & $\begin{array}{c}\text { Corresponding \% } \\
\text { Conventional } \\
\end{array}$ \\
$\begin{array}{cc}\text { Embankment } \\
\text { Material Passing } \\
\text { No.4 Sieve }\end{array}$ \\
\hline 0 & $100 \%$ \\
$20 \%$ & $80 \%$ \\
$40 \%$ & $60 \%$ \\
$60 \%$ & $40 \%$ \\
$100 \%$ & $0 \%$ \\
\hline
\end{tabular}

exerted for every layer of soil both for the preparation of sample for consolidation and direct shear test. Moreover, the saturation of the sample was also checked after every test to make sure that the sample was is in its saturated state.

\section{Direct Shear Test}

The direct shear test had a total of 90 trials. There were three varying normal loads for the test: $81.75 \mathrm{kPa}, 109$
$\mathrm{kPa}$ and $136.25 \mathrm{kPa}$. These loads were the approximate loads for structural buildings. Two trials were successfully done for each type of specimen. All specimens were fully saturated so as to simulate worst case scenario of the embankments. The relative compaction used in this study was between $90-95 \%$, the commonly used relative compaction in the construction of embankments.

The three conditions considered for this test were the following: Unconsolidated Undrained (UU), Consolidated Undrained (CU) and Consolidated Drained (CD). For the Undrained test the rate of shearing was $1.25 \mathrm{~mm} / \mathrm{min}$ which was derived from Soil Properties: Testing Measurement and Evaluation (Liu and Evett, 1990) . The book suggests a shearing rate of $0.05 \mathrm{in} / \mathrm{min}$ which is approximately $1.25 \mathrm{~mm} / \mathrm{min}$ when converted to metric. For the drained test, the rate of loading used was determined through the formula, Time of Failure $(\mathrm{tf})=$ $50 t_{50}, t_{50}$ was obtained using the square-root-of-time method. The time of consolidation used for the study was 3 hours.

\section{TEST RESULTS}

The geotechnical properties of the five blends were investigated and used to obtain different empirical relationships. The summary of the values are shown in Table 3.

\section{A. Specific Gravity}

Experiments show that $100 \%$ limestone has a specific gravity of 2.63 which is within the range of $2.58-2.65$ for carbonate materials [1]. On the other hand, for the $0 \%$ limestone, the specific gravity is 2.89 which is in the range of typical values for silty soils [5]. With the increasing amount of limestone, there is a decreasing value which can be attributed to the mineralogical component of the sample.

A polynomial equation in the second degree which can estimate specific gravity for different limestone content is derived as shown in Equation (1).

$$
\text { Gs }=0.00003(\mathrm{LC})^{2}-0.0054(\mathrm{LC})+2.8827
$$

where;

$\mathrm{Gs}=$ specific gravity of solids; and $\mathrm{LC}=$ limestone content in $\%$.

\section{B. Minimum and Maximum Index Densities}

The control blend shows the highest value for both the

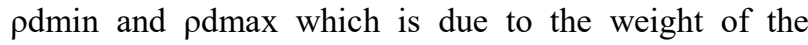
particles. The control blend has higher specific gravity which means that it is heavier as compared to the limestone.

From these values, the emax and emin were computed as shown in Table 2. Among the five samples, the control blend, $0 \%$ limestone, is the densest while the $100 \%$ limestone has the largest void ratio. 
The Third International Conference on Civil Engineering Research (ICCER)

A $\quad$ Table2. Maximum and Minimum Void Ratios

\begin{tabular}{ccc}
\hline $\begin{array}{c}\text { Limestone } \\
\text { Content }(\%)\end{array}$ & $\mathrm{e}_{\max }$ & $\mathrm{e}_{\min }$ \\
\hline 0 & 0.69 & 0.32 \\
20 & 0.74 & 0.37 \\
40 & 0.87 & 0.43 \\
60 & 0.93 & 0.48 \\
100 & 1.20 & 0.76 \\
\hline
\end{tabular}

The maximum and minimum void ratios are affected by several factors such as the grain size, grain shape, nature of the distribution curve and the fine contents [5]. Since there is a grain size distribution followed as specified in the methodology, the samples used can be defined as a well-graded sample. The fines content for both the $0 \%$ limestone and $100 \%$ limestone are equal in proportion. The main factor affecting the void ratio of the blends is the grain shape. Because of the range of the angularity of the particles, lesser spaces are left thus resulting to a lesser void ratio.

Equations (2) and (3) were derived to estimate the maximum and minimum void ratios in terms of limestone content, respectively.

$$
\begin{aligned}
& \mathrm{e}_{\max }=0.00002(\mathrm{LC})^{2}+0.0031(\mathrm{LC})+0.6874 \\
& \mathrm{e}_{\min }=0.00004(\mathrm{LC})^{2}+0.0006(\mathrm{LC})+0.3331 \\
& \text { where; } \\
& \mathrm{e}_{\max }=\text { maximum void ratio; } \\
& \mathrm{e}_{\min }=\text { minimum void ratio; } \\
& \text { and LC = limestone content in } \% .
\end{aligned}
$$

\section{Atterberg Limits}

It shows the amount of limestone increases, the LL and PL increases its values as well. The control blend has a very low PI which is equal to 1,89 . On the other hand, for the $100 \%$ limestone, PI is equal to 4.59 . A limestone filler has a plasticity index generally under 4 [6]. 100\% limestone can be classified as low plastic while the control blend, $20 \%, 40 \%$ and $60 \%$ are classified as slightly plastic. The control blend is expected to have a low value of PI since it is a cohesionless type of soil.

Equations (4), (5), and (6) were derived to estimate the liquid limit, plastic limit and plasticity index in terms of limestone content, respectivey.

$$
\begin{aligned}
& \mathrm{LL}=0.00001(\mathrm{LC})^{2}+0.0529(\mathrm{LC})+13.515 \\
& \mathrm{PL}=-0.00001(\mathrm{LC})^{2}+0.0458(\mathrm{LC})+11.599 \\
& \mathrm{PI}=0.0002(\mathrm{LC})^{2}+0.0071(\mathrm{LC})+1.9158 \\
& \text { where; } \\
& \mathrm{LL}=\text { liquid limit; } \\
& \mathrm{PL}=\text { plastic limit; } \\
& \mathrm{PI}=\text { plastic limit; } \\
& \text { and } \mathrm{LC}=\text { limestone content in } \%
\end{aligned}
$$

\section{Direct Shear Test}

Cohesion is a shear strength parameter of a soil wherein the adsorbed water and particle attraction work with each other in order to create a mass which holds to the soil together [7]. The cohesion versus Limestone content from UU,CU and CD tests are shown in Figures

Table 3. Summary of the Index Properties

\begin{tabular}{ccccccc}
\hline & & & & & & \\
$\begin{array}{c}\text { Limestone } \\
\text { Content } \\
(\%)\end{array}$ & $\begin{array}{c}\text { Specific } \\
\text { Gravity } \\
\left(\mathrm{G}_{\mathrm{s}}\right)\end{array}$ & $\begin{array}{c}\rho_{\mathrm{dmax}} \\
\left(\mathrm{g} / \mathrm{cm}^{3}\right)\end{array}$ & $\begin{array}{c}\rho_{\text {dmin }} \\
(\mathrm{g} / \mathrm{cm} \\
3\end{array}$ & LL & PL & PI \\
& & & & & & \\
\hline 100 & 2.63 & 1.49 & 1.19 & 19.70 & 15.11 & 4.59 \\
60 & 2.67 & 1.81 & 1.38 & 17.29 & 14.42 & 2.87 \\
40 & 2.71 & 1.89 & 1.45 & 15.82 & 13.13 & 2.68 \\
20 & 2.77 & 2.03 & 1.59 & 14.20 & 12.07 & 2.12 \\
0 & 2.89 & 2.18 & 1.71 & 13.73 & 11.84 & 1.89 \\
\hline
\end{tabular}

2,3 and 4 , respectively.

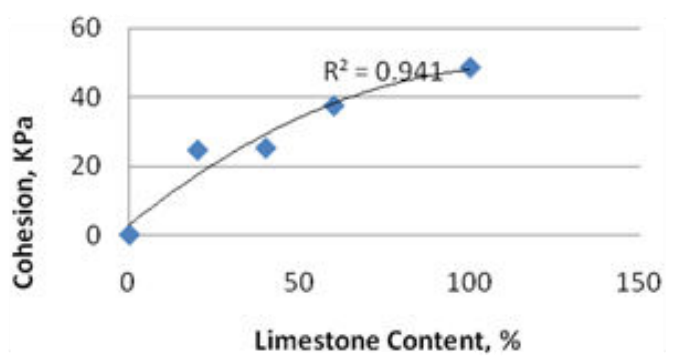

Figure 2. Cohesion vs Limestone Content from Unconsolidated Undrained test

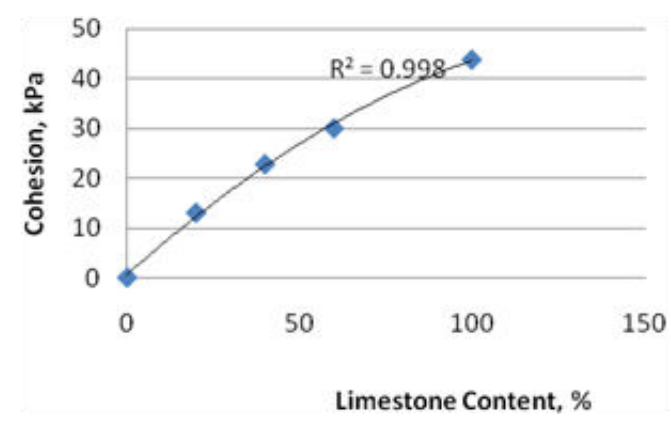

Figure3. Cohesion versus Limestone Content from Consolidated Undrained test

The equations which can be derived from the behaviour of soil based on the direct shear test are shown in Equations (7), (8), and (9).

For Unconsolidated Undrained:

$c^{\prime}=-0.0034 L^{2}+0.7899 L C+2.9756$

For Consolidated Undrained:

$c^{\prime}=-0.0019 \mathrm{LC}^{2}+0.6222 \mathrm{LC}+0.5184$

For Consolidated Drained:

$c^{\prime}=-0.0017 \mathrm{LC}^{2}+0.4089 \mathrm{LC}+1.781$

where;

$\mathrm{c}^{\prime}=$ cohesion in $\mathrm{kPa}$, and;

$\mathrm{LC}=$ limestone content of the sample in percent. 


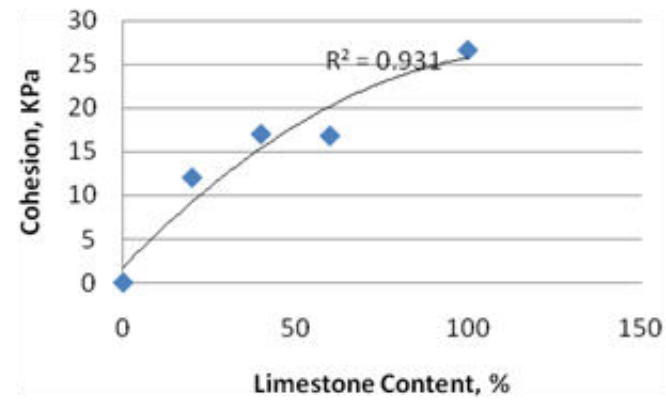

Figure4. Cohesion vs Limestone Content from Consolidated Drained test

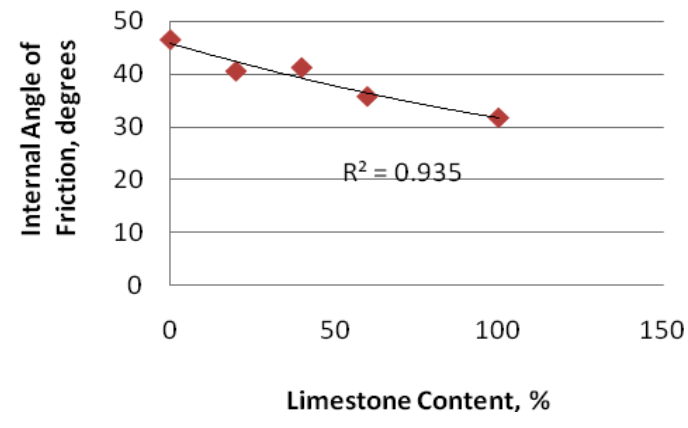

Figure5. Internal Angle of Friction vs Limestone Content (\%) from Unconsolidated Undrained Test

The behaviour of the graphs shown in figures $2,3 \& 4$ indicate that as the limestone content increases the cohesion also increases. The plasticity of the soil is a factor which affects the cohesion. It was presented earlier that the addition of limestone increases the plastic index of the blends

According to [8], the excess water pressure increases the shear strength of the soil, which also means that there is an increase in its parameters such as the cohesion.

\section{E. Angle of ilnternal Friction}

The angle of internal friction is the sliding resistance between particles which is influenced by the following conditions: effective stress, coefficient of friction between the minerals, surface roughness, and the angle of contact between grains [7]. Figures 5, $6 \& 7$ show the angle of internal friction versus limestone content for UU, CU and CD, respectively.

The equations derived from the three tests are shown in Equatons (10), (11), and (12):

For Unconsolidated Undrained:

$\phi=0.0004 \mathrm{LC}^{2}-0.1816 \mathrm{LC}+45.907$

For Consolidated Undrained:

$\phi=-0.0006 \mathrm{LC}^{2}-0.1 \mathrm{LC}+46.786$

For Consolidated Drained:

$\phi=-0.0002 \mathrm{LC}^{2}+0.0327 \mathrm{LC}+43.493$

where,

$\phi=$ internal angle of friction of the limestone blend in degrees, and

LC $=$ limestone content of the sample (\%).

Figures 5, 6 and 7 show that there is a decrease in the internal angle of friction for every increase in limestone content. The internal angle of friction is dependent on the

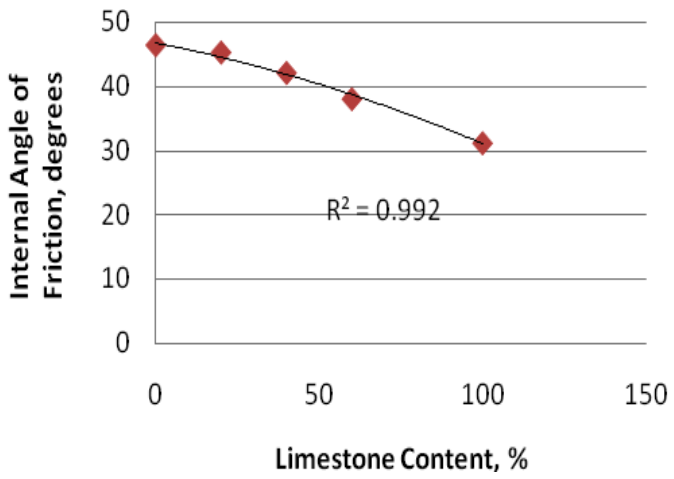

Figure 6. Internal Angle of Friction vs Limestone Content $(\%)$ from Consolidated Undrained Test

shape of the soil. The shape of the conventional embankment material is considered to be subangular to angular while the limestone has a subrounded shape. The conventional embankment material contributes to the increase of internal angle of friction because of the angle of contact of its particle due to its angular shape.

\section{F. $\quad$ Stress-Strain Relationship}

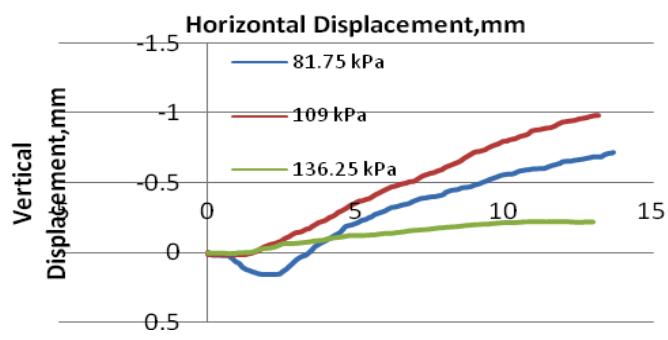

Figure 9. Vertical Displacement vs. Horizontal displacement from 0\% Consolidated Drained test

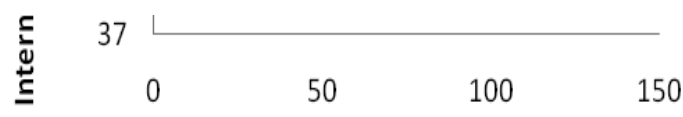

Limestone Percentage, \% 


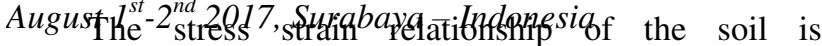
anisotropic meaning that it has different behaviours for different directions (Budhu, 2000). In the direct shear test the stress-strain diagram was taken from the graph of the shear force versus the shear displacement. Figure 8 best represent the stress strain diagram of the different

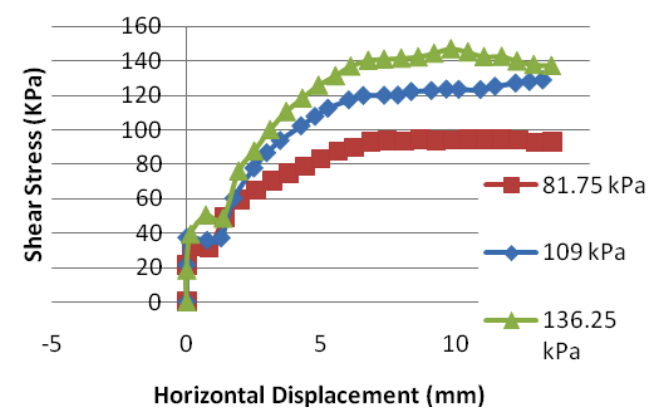

Figure8. Stress-strain diagram of Unconsolidated Undrained $40 \%$ Limestone Content

blends

The graph in Figure 8 was derived from the unconsolidated undrained test of $40 \%$ limestone content and it was found out through the observation of the diagram that the soil is considered to be elastoplatic. At first, the soil behaves nonlinearly elastic then was subjected to plastic deformation. This behaviour was applicable for all the blends and also for the Consolidated Undrained and Consolidated Drained tests. Due to the elastoplastic behaviour, the parameters derived from the direct shear test falls under the critical state which is defined as the stress state reached in a soil when continuous shearing occurs at constant volume and shear stress [9].

The normal stress applied affects the stress-strain behaviour of the soil which was tested. As the normal stress increases, the shear stress also increases. This is due to the friction produced by the normal force during the shearing process.

\section{G. Dilatancy}

The vertical displacement of the specimen during shear can be related to its density. Figure 9 represents the same behaviour for all consolidated tests (CD and CU) for all the blends. The dilatancy occurred because there was a preconsolidation stress applied to the sample and when the shear stress was applied a certain angle of dilation occurred which yielded the graph For the Unconsolidated Undrained tests, compression was observed since the soil sample was subjected to vertical stress and horizontal stress simultaneously.

\section{H. Shear Strength Properties and Plasticity Index}

Das (2011) stated that the plasticity of the soil affects its internal angle of friction. It can be seen in figure 10 that as the plasticity index increases there is a corresponding decrease in the internal angle of friction of the soil. The difference in behaviour of the drained and undrained condition of the soil can also be observed. In the graph, the drained condition has a gentler slope, meaning the decrease in internal angle of friction of the soil is more gradual than that of the undrained condition

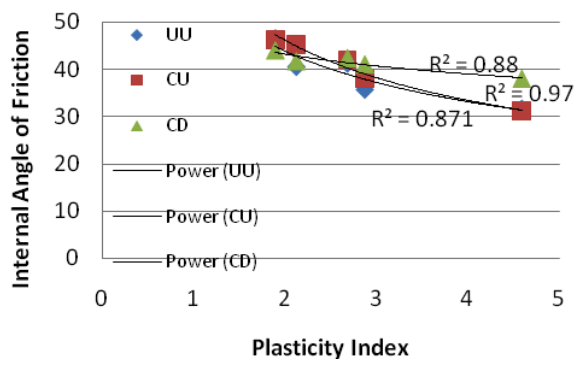

Figure 10. Variation Internal Angle of Friction with Plasticity Index (PI) for the different direct shear test displacement from $0 \%$ Consolidated Drained test

Emprical relationships between angle of internal friction and plasticity index were also derived as shown in Equations, (13), (14), and (15).

For Consolidated Drained,

$\mathrm{y}=47.95 \mathrm{x}-0.15$

For Consolidated Undrained,

$\mathrm{y}=57.683 \mathrm{x}-0.4$

For Unconsolidated Undrained,

$y=63.49 x-0.462$

For the cohesions of the blends, it is best described by a second degree relationship with the Plasticity Index of the soil (figure 11). Meaning, that there would be a certain Plasticity Index wherein the cohesion of the soil would peak and produce the maximum cohesion which is approximately 4.1. 


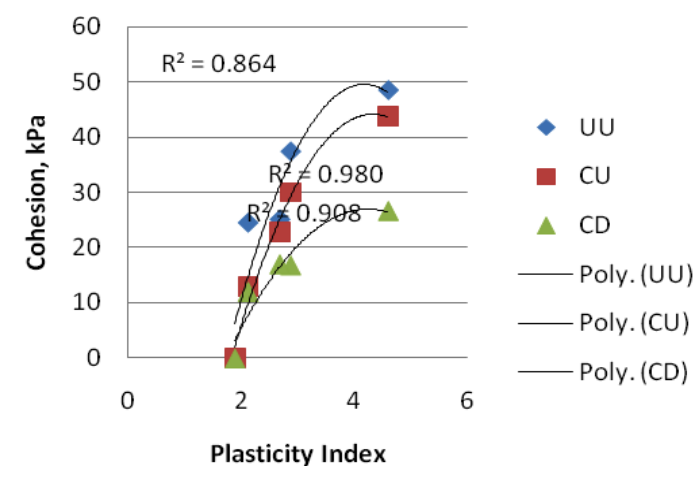

Figure 11. Relationship between the Cohesion and Plasticity Index of the Blends

Equations (16), (17), and (18) were derived from the correlation of the samples between the cohesion and the plastic index shown in figure 11.

where;

$c^{\prime}=$ Cohesion and;

PI = Plastic Index,

For Consolidated Drained,

$c^{\prime}=-4.2713$ PI $2+36.299$ PI -50.162

For Consolidated Undrained,

$c^{\prime}=-7.0947 \mathrm{PI} 2+61.396 \mathrm{PI}-88.637$

For Unconsolidated Undrained,

$c^{\prime}=-8.2956$ PI $2+69.328$ PI -95.206

\section{SUMMARY AND CONCLUSIONS}

The direct shear tests conducted show the relationship of its strength parameters (cohesion and angle of internal friction) with the amount of limestone in the mix. There is a noticeable increase in the cohesion with the increase of limestone. Opposite trend was observed for the angle of internal friction. Equations for various combinations were introduced to give an estimate for geotechnical parameters like specific gravity, index densities and Atterberg limits. Equations to compute for cohesion and angle of internal friction for different limestone contents were also introduced.

\section{REFERENCES}

[1] B. Felekoglu, "Utilisation of high volumes of limestone quarry wastes in concrete industry (self-compacting concrete case)," Resour. Conserv. Recycl., vol. 51, pp. 770-791, 2007.

[2] D. S. Ramer, "Performance of Roadway Embankments on Lime Waste," Geotech. High Water Content Mater. ASTM STP 1374, pp. 351-361, 2000.

[3] R. Dunlop, "Reviews of Roads with lime/cement pavement layers," AusUan Road Res., vol. 10, no. 3, pp. 12-26, 1998.

[4] K. Chao, Soil Water Retention curves for Remolded Expansive Soils. . Engineering Analytics, Inc., 2008.

[5] B. Das, Fundamentals of Geotechnical Engineering. Thomson Learning, 2006.

[6] G. Chilingar, Asphaltenes and asphalts, 2nd ed. Netherland: Elsevier Science, BV, 2000.

[7] G. Sowers, Introductory Soil Mechanics and Foundations. The Macmillan Company, 1961.

[8] J. Duncan, Soil Strength and Slope Stability. New Jersey: John Wiley \& Sons, Inc.

[9] M. Budhu, Soil Mechanics \& Foundations. New York: John Wiley \& Sons, Inc., 2000. 